\title{
Memórias de uma ausência: mulheres sem filhos e suas narrativas sobre maternidade no Paraná do século XX
}

\section{Memories of an absence: Women without children and their narratives about motherhood in Paraná on the 20th Century}

\author{
Georgiane Garabely Heil Vázquez*
}

\begin{abstract}
Resumo
Buscou-se neste artigo problematizar sobre como mulheres não-mães reconstroem suas recordações a respeito da maternidade, ou seja, como elas se colocam diante de tão vasta campanha desfraldada ao longo do século XX em prol da suposta obrigação feminina em ser mãe. Para fins metodológicos esta pesquisa se ancora nos princípios da história oral com o intuito de debater sobre as reconstruções e significações da memória feminina sobre a experiência de não ser mãe. As entrevistas das mulheres não-mães estão divididas em três grandes grupos. O primeiro grupo é ocupado por mulheres que nasceram nas décadas de 1920 e 1930, que neste artigo estão classificadas como de $1^{\circ}$ geração. O segundo grupo é composto por mulheres que nasceram nas décadas de 1940 a 1950, que compõem a $2^{\circ}$ geração. Já o terceiro grupo é formado por jovens senhoras que nasceram em plena revolução sexual, isto é, nas décadas de 1960 e 1970 e, portanto, entraram na vida sexual/ reprodutiva num momento de maior disponibilidade de tecnologias e métodos para evitar a gestação assim como para promovê-la, se desejado. As entrevistas nos mostraram a imensa pluralidade existente entre essas mulheres não mães, o que demonstra a agência desses sujeitos para além das tentativas de categorização efetuadas sobre mulheres sem filhos.
\end{abstract}

Palavras Chave: maternidade, sentimentos, filhos, mulheres.

\begin{abstract}
This research intends to problematize how non-mothers reconstruct their memories of motherhood and how they situate themselves amongst the massive campaign of the 20th Century upholding the alleged female obligation to bear children. Methodologically, the research is based on the principles of oral history in order to discuss the reconstructions and significations performed by the interviewees concerning their experience of not being mothers. The interviews with non-mothers are divided in three great groups.
\end{abstract}

* Doutora em História pela Universidade Federal do Paraná. Professora da Faculdade Sagrada Família (FASF). E-mail: profgeorgiane@hotmail.com 
The first group, referred to as 1st generation, is formed by women born in the 1920 s and 1930s. The second group, or 2nd generation, comprises women born in the 1940s and 1950s. The third group is constituted by women born amidst the sexual revolution, that is, in the 1960s and 1970s, who initiated their sexual/reproductive lives in a period when contraceptive as well as conceptive technologies and methods became more available. The interviews reveal the immense plurality among non-mothers, pointing to how each woman's agency exceeds the attempts to categorize them.

Keywords: motherhood, feelings, children, women.

\section{Notas preliminares}

Não deixe que a mão rude do inverno apague o verão que foi você e que o moldou; Em algum frasco guarde, em algum lugar mantenha, o tesouro da beleza que antes existiu. Este a to não é usura proibida(...) Cabe a você, em outro se tornar. Dez vezes o seu eu se torna mais feliz, se dez de você em outros dez o criarem. O que pode então fazer a morte se você parte deixando os seus eus vivos na posteridade? Não seja um alvo da vitória da morte, deixando os vermes como herdeiros.

(Shakespeare)

Este estudo ao se vincular com a abordagem analítica de gênero a respeito de mulheres que nunca foram mães, e que, portanto, não geraram biologicamente um filho ${ }^{1}$ nem tampouco se propuseram a adotar um, procurou compreender como essas mulheres reconstruíram suas experiências de não-mães em um período histórico de extrema valorização da maternagem, o século XX.

Ao longo do século XX, a maternidade foi alvo de uma intensa campanha por parte dos governos e da sociedade de um modo geral, não sendo por acaso que o referido século se consolidou como "o século da criança". Nesse sentido, a maternidade não deveria ser definida apenas como um fenômeno biológico (mulheres engravidam porque seus corpos foram concebidos para isso), mas como fundamental para a continuidade da espécie, daí a defesa e a reiteração do argumento da afetividade, do amor materno e incondicional.2

\footnotetext{
${ }^{1}$ As mulheres que, por problemas biológicos ou de outra espécie, não geraram um filho mas adotaram crianças não fazem parte deste estudo. Parto do princípio que a maternidade é mais social do que biológica e, dessa forma, a adoção efetiva de uma criança caracteriza a vivência da experiência de maternidade.

${ }^{2}$ BADINTER, E. Um amor conquistado: O mito do amor materno. Rio de Janeiro: Nova Fronteira, 1985.
} 
Assim, o "problema" da impossibilidade de gerar filhos ou a recusa em engravidar, foram culturalmente vinculados à ideia de uma incapacidade feminina, uma falha, uma imperfeição no corpo da mulher. ${ }^{3}$ A construção da fertilidade foi estabelecida nas sociedades como uma das mais importantes funções da vida adulta, devido a isso, uma série de cuidados, preparações e até "rituais" foram estabelecidos para enaltecer a reprodução humana e, no extremo oposto, a dificuldade em procriar ou mesmo a opção pela ausência de filhos se tornaram problemas de dimensões significativas em muitas sociedades.

Magali Engel ${ }^{4}$ afirma que as mulheres que ficaram à margem da maternidade foram representadas de um modo caricaturesco e até mesmo consideradas inferiores. Por ser o século XX um período de extrema valorização da criança, a maternidade foi vista como a verdadeira essência da mulher, ou seja, inscrita numa espécie de "natureza feminina". Desta forma, aquelas que não foram mães, pelos mais variados motivos, poderiam ser vistas como seres física, moral ou psicologicamente incapazes, além disso, as não-mães, para a literatura médica de até metade do século XX, teriam uma disposição maior para a loucura e a insanidade.

É importante mencionar que ser mãe ou não ser mãe é antes de tudo uma experiência cultural. Dessa forma, considero significativas as reflexões de Françoise Thébaud ${ }^{5}$ a qual afirma existir um campo de estudos sobre a maternidade que ainda carece de inúmeras investigações. O filho, desejado ou recusado, e a gravidez, levada a cabo ou interrompida, ajudam a compor a historicização da maternidade. Tal processo é fundamental para evidenciar que entre "a mãe" e a "não-mãe" há uma pluralidade de experiências, subjetividades e sentimentos, nem sempre coerentes ou coesos com o ideal social formulado sobre elas.

As problematizações tiveram como objetivo compreender como as mulheres não-mães se sentiam ao perceberem que chegavam próximas do fim da vida reprodutiva sem um descendente. Também foi um dos objetivos dessa análise perceber como as mulheres que não tiveram filhos lidam com tamanha valorização da maternidade e do bebê. Outro ponto debatido foi como se perceberam a partir da perspectiva do grupo social diante de sua condição de não-mãe. Foram realizadas dezessete entrevistas com mulheres que não

\footnotetext{
${ }^{3}$ GERR, G. Sexo e Destino: a política da fertilidade humana. 2ed. Rio de Janeiro: Rocco, 1987.

${ }^{4}$ ENGEL, Magali. "Psiquiatria e feminilidade”. In: História das Mulheres no Brasil(org). São Paulo: Contexto, 1997. ${ }^{5}$ THÉBAUD, Françoise. “O medo do ventre”. In: Amor e Sexualidade no Ocidente. 2ed. Lisboa: Terramar, 1998.
} 
tiveram filhos e este artigo apresenta trechos de algumas dessas entrevistas, destacando aquelas que mencionaram com mais evidência o sentimento de solidão ou a recusa a este sentimento.

As entrevistas estão divididas em três grandes grupos, que classifiquei neste trabalho como três gerações. O primeiro grupo, que chamo de primeira geração, é composto por mulheres que nasceram nas décadas de 1920 e 1930, ou seja, são mulheres nascidas ainda na primeira metade do século XX e que, portanto, iniciaram sua vida sexual-reprodutiva antes da chamada revolução sexual. Dessa forma, a primeira geração de mulheres viveu sua mocidade numa época de pouca opção para se evitar filhos. Via de regra, o celibato para mulheres solteiras e o coito interrompido ou abortos caseiros para as casadas eram as formas encontradas para evitar a maternidade. É significativo mencionar que foram feitas três entrevistas com mulheres pertencentes a primeira geração. Embora o número pareça reduzido, considero que qualitativamente as entrevistas possibilitaram reflexões sobre a ausência de maternidade na primeira metade do século XX. Outro ponto que merece ser mencionado ainda tratando da primeira geração é que, embora tenha procurado por diferentes meios, só consegui mulheres solteiras e sem filhos pertencentes a esta geração. Acredito que a maternidade era fortemente valorizada como uma espécie de "consequência natural" do casamento e, portanto, as mulheres casadas que não conseguiam ter filhos biológicos, via de regra, adotavam ou "pegavam para criar", alguma criança da família ou alguma criança abandonada. Desta forma, não foi possível encontrar casadas e sem filhos pertencentes à primeira geração.

O segundo grupo, ou segunda geração, é composto de mulheres nascidas nas décadas de 1940 e 1950, tendo iniciado sua vida sexual-reprodutiva em plena revolução sexual. Já o terceiro grupo, com mulheres nascidas nas décadas de 1960 e 1970, iniciou a vida sexual após a revolução sexual e muitas dessas possuem chances de ter filhos (idade, saúde). As mulheres da terceira geração já conviveram com discursos acerca de reprodução assistida, a disponibilidade comercial da pílula e mesmo a "barriga fraterna ou solidária". ${ }^{6}$ Elas, portanto, possuem um leque mais amplo de escolha sobre ter ou não ter filhos. Porém, por motivos variados, ainda não viveram a experiência da maternidade ou simplesmente optaram pela não-maternidade. A estratégia

\footnotetext{
${ }^{6}$ Chama-se de "barriga fraterna ou solidária" quando a mulher não possui condições de manter a gestação e seu óvulo é introduzido, já fecundado, em outro útero. Essa prática, segundo a legislação brasileira, não pode envolver pagamento de espécie alguma e deve ser realizada entre membros da família da mulher. É mais comum que a mãe ou a irmã gerem o filho para a mulher impossibilitada de gestar.
} 
de dividir mulheres por gerações não partiu de uma visão estanque na forma como pensam e agem tais pessoas. Não verifiquei latente exclusividade de sentimentos com relação à ausência de maternidade na primeira, na segunda ou na terceira gerações. Meu intuito foi, antes de tudo, tentar organizar, de alguma maneira, a engrenagem do tempo. Propor um estudo que abarque quase um século é tarefa complexa, e a estratégia metodológica de dividir as entrevistas por categorias geracionais foi a forma encontrada para melhor sistematizar a pesquisa.

Jean-François Sirinelli ${ }^{7}$ ao abordar o uso do conceito de geração para a pesquisa com história oral, levanta seus obstáculos e potencialidades. Para ele, uma das principais dificuldades é que existe uma noção de periodização que nos remete à regularidade vinculada à ideia de geração. Essa noção deve ser problematizada a fim de que suas limitações fiquem salientes. Os fatos inauguradores de uma época, ou de "uma geração", se sucedem de forma irregular, ou seja, questões econômicas, sociais, políticas e culturais não avançam ou retroagem com a mesma intensidade ou o mesmo ritmo. Assim, "as gerações" relacionadas aos diferentes registros históricos não podem ser formuladas de maneira "geométrica", mas sim com flexibilidade. A flexibilidade sugerida pelo autor foi levada em consideração nos momentos em que as entrevistas foram realizadas e analisadas. Falas semelhantes aparecem em gerações diferentes e, portanto, não é o ano de nascimento que determina certo pensamento ou sentimento com relação à ausência de filhos. A geração serviu para estabelecer uma divisão metodológica no momento de realizar as entrevistas, mas também ficou evidente que é uma interessante "[...] escala móvel do tempo."8 A noção de geração se transformou em um potente instrumento categorial e de análise, pois evidenciou que as transformações e as permanências não se dissolvem obrigatoriamente com a passagem dos anos e dos dias. Mais especificamente, possibilitou analisar as pluralidades das visões multifacetadas e as descontinuidades relativas aos sentimentos e desejos sobre a experiência da ausência de maternidade ao longo do século XX.

Considero pertinente mencionar que outro fator me levou a usar como estratégia metodológica a geração. Esse fator diz respeito à determinação da idade do grupo de mulheres selecionadas. Procurei fazer entrevistas com mulheres acima de 35 anos em virtude das questões do corpo e das possibilidades de gravidez. Segundo relatório da Organização Mundial da Saúde (OMS),

\footnotetext{
${ }^{7}$ SIRINELLI, Jean. F. “A Geração”. In: Usos e abusos da História Oral. 8ed. Rio de Janeiro: FGV, 2008. ${ }^{8} \mathrm{Ibidem}, \mathrm{p} .135$.
} 
divulgado em 1981, a menopausa, também conhecida como climatério, começaria por volta dos 35 anos de idade e terminaria aos 65 anos, ou seja, duraria 30 longos anos. Ainda segundo esse documento, nos primeiros 10 anos, dos 35 aos 45 , as mulheres teriam um período pré-climatério, dos 45 aos 55 anos, seria o climatério propriamente dito, e dos 55 até os 65 anos um período pós-climatério. Todavia, é necessário se ter clareza de que "[...] a menopausa e o envelhecimento fazem parte de um processo biológico inexorável, quando todas as fêmeas da espécie humana param de produzir hormônios, significando somente o final da vida reprodutiva e não o fim da vida." ${ }^{9}$ Destarte, o processo biológico da menopausa deveria ser visto como mais um dos inúmeros ritos de passagem que os antropólogos apontam no decorrer da vida humana e não como uma crise profunda. O período da menopausa é uma fase de transição e não um período de "crise de produção", pois as capacidades femininas e o papel efetivo das mulheres em toda a teia de relações sociais não podem ser determinados pela capacidade ou incapacidade em produzir crianças, como se fossem máquinas biológicas.

Todas as mulheres selecionadas para este estudo já atravessaram ou estão próximas do climatério, pelo menos do que poderíamos chamar de primeira fase do climatério, e entender a chegada a esse momento vital, sem a geração de um filho, foi um dos objetivos desta pesquisa. Analisar as narrativas dessas mulheres sobre a pluralidade de experiências vinculadas a ausência de filhos é o que apresentarei doravante.

\title{
Do filho que quis e nunca tive
}

\author{
Oh, pedaço de mim \\ Oh, metade arrancada de mim \\ Leva o vulto teu \\ Que a saudade é o revés de um parto \\ A saudade é arrumar o quarto \\ Do filho que já morreu... \\ (Chico Buarque)
}

A ideia de "ausência" não é aqui entendida como uma experiência linear e constante na vida de todas as mulheres sem filhos, contudo, a cobrança ou o questionamento em torno dessa ausência foi comum para as mulheres entrevistadas. Em alguns casos, as próprias mulheres se colocaram diante da

\footnotetext{
${ }^{9}$ AMARAL, Luciana. “Menopausa: uma crise de produção?” In: Coletânea Gênero Plural . Curitiba: UFPR, 2002, p. 139.
} 
questão da ausência de filhos, e em outros, elas foram questionadas por familiares, amigos ou mesmo por seus companheiros, seus maridos. Assim, minha ambição foi de estudar a "presença de uma ausência", ou seja, compreender como as entrevistadas lidaram com a ausência de filhos. Filhos que nunca existiram fisicamente, mas que chegaram a existir em desejo/vontade, para algumas, ou então em pressão/cobrança, para outras. Com isso, não pretendo criar uma oposição entre as mulheres sem filhos. Não se trata de dividi-las simplesmente entre aquelas que sofrem pela ausência de filhos e aquelas que sofrem pelas cobranças a respeito de filhos que não desejam ter.

Contudo, acredito que, a partir dessas duas situações, a princípio opostas, posso demonstrar as complexidades subjetivas que envolvem cada um dos campos. Elas sentiram, viveram e lidaram com a ausência de filhos de maneiras diferentes. Tal variação foi, sem dúvida, um complicador teórico e metodológico, mas foi também a motivação para abandonar a ideia de oposição de experiências (umas não querem ter e são cobradas, outras querem ter e sofrem por, de alguma forma, não poderem). No lugar dessa oposição, operei com a ideia de multiplicidade de sentimentos, explicada pela complexidade contextual e subjetiva das mulheres entrevistadas.

Constatei que suas vidas não se limitaram e nem foram reduzidas pela experiência de não-maternidade. A ausência, o desejo de engravidar, de ter uma criança para conviver no cotidiano faz parte de suas histórias, mas não impedem que tais mulheres construam novas e diferentes sociabilidades, e que planejem suas vidas e a busca de felicidade individual de maneira diversificada.

Salvina, ${ }^{10}$ nascida em Manaus/ AM em 1960, mas residente na cidade de Ponta Grossa/PR a mais de uma década, desejou em diferentes momentos ser mãe. Mas sua vida foi tomando outro rumo e suas possibilidades de engravidar foram se tornando cada vez mais remotas devido à idade. Quando lhe perguntei se ela gostaria de ter tido um filho, um longo e perturbador silêncio tomou conta da pequena sala reservada na biblioteca onde a entrevista aconteceu. Depois de silenciar e de me olhar nos olhos, ela me respondeu:

No fundo eu queria ter um filho... mas, porque? Talvez eu tentasse dar pra ele tudo o que eu não tive... queria dar pai e mãe, que eu não tive, porque eu sou mais mãe da minha mãe, do que ela de mim. Até hoje eu dou bronca na minha mãe, tenho que educar minha mãe. Eu tive minha madrinha, ela não teve filhos e me sufocou muito. Eu não tenho amigos, não converso com ninguém sobre minha vida intima. Hoje tô conversando com você... Talvez ter um filho pra

\footnotetext{
${ }^{10}$ Todos os nomes das entrevistas foram alterados por questões de ética de pesquisa. Solicitei que as entrevistadas escolhessem novo nome ou então lhes atribuí novo nome, nos casos que me permitiram.
} 
saber que era meu, que saiu de mim. Acho que é essa sensação porque quando olho pra uma mulher grávida penso: ai que coisa mais linda! Cuido dos meus sobrinhos, tenho sentimento e preocupação com eles... mas não sei o que é ser mãe de parir. Quando vejo a mulherada fico olhando pra barriga. Sinto falta de ter essa experiência. Se eu faço massagem na mulherada quando estão grávidas, nossa, que delícia. Eu falo... “Jesus, eu sou mãe”, porque fico fazendo massagem naquela barriga. Os bebês conhecem a minha voz, fez massagem nove meses e não vai conhecer a mão da massagista [risos], conhece de longe o bichinho. (Salvina - terceira geração). ${ }^{11}$

Segundo Luci Helena Mansur ${ }^{12}$, a grande maioria das mulheres cria as concepções do que é ser mãe a partir das suas experiências com suas mães. Dessa forma, o ato de optar por não ter um filho, ou não conseguir ter um filho, pode significar cortar um vínculo com a própria mãe, diferenciando-se dela com relação à procriação e às afetividades. Cabe destacar que não existe uma relação simples e linear entre a experiência com a mãe, como a narrada por Salvina, e a não-maternidade. Salvina afirma que gostaria de ter tido filhos para dar a eles tudo o que não teve. Ela menciona que por diversas vezes teve que cuidar da mãe, aconselhar e até dar broncas.

Desse modo, num primeiro momento, supus que havia uma relação entre experiências familiares negativas e a escolha deliberada pela não-maternidade. Contudo, minhas impressões iniciais foram contrariadas em dois importantes momentos. No primeiro, quando me deparei com a pesquisa de Jeanne Safer, ${ }^{13}$ cuja investigação sobre a ausência de maternidade por meio de entrevistas com cinquenta mulheres nos Estados Unidos constatou que as experiências familiares conturbadas são relatadas tanto por mulheres que tiveram filhos como por aquelas que não tiveram. Um ponto central nas reflexões de Safer diz respeito ao ato do filho como reparação. Algumas mulheres querem ter filhos justamente para reparar algo que consideraram incompleto ou imperfeito nas relações com suas mães. Tomar as relações mãe e filha como ponto central e explicação para a não-maternidade foi considerado pela autora como impreciso e talvez mesmo inadequado para interpretar experiências de vida tão plurais.

Assim, num segundo momento de revisão sobre minhas impressões iniciais a respeito da não-maternidade, percebi que "o campo", ou seja, elas, as mulheres entrevistadas, não colocavam sobre suas mães o peso das escolhas ou

\footnotetext{
${ }^{11}$ Entrevista concedida em 04 de maio de 2013.

${ }^{12}$ MANSUR, Maria, H. Sem filhos: a mulher singular no plural. São Paulo: Casa do Psicólogo, 2003.

${ }^{13}$ SAFER, Jeanne. Além da maternidade. Optando por uma vida sem filhos. São Paulo: Mandarim, 1997.
} 
circunstâncias que as levaram à não-maternidade. Percebi que as entrevistadas se aproximavam pelo fato de não terem filhos, mas eram muito diferentes os caminhos percorridos nessa experiência. Salvina, por exemplo, teve um pai violento ${ }^{14}$ e uma mãe conivente com a violência por cerca de oito anos. Depois disso, a mãe fugiu com os filhos passando a enfrentar dificuldades financeiras, obrigando-a a trabalhar fora e deixar sobre Salvina a responsabilidade de cuidar dos irmãos. Portanto, as experiências familiares conturbadas na infância, e posteriormente na adolescência, não representaram uma opção pela não-maternidade. Ao contrário disso, Salvina gostaria de ter tido filhos e não os teve devido ao fato de que se casou mais tarde e de que só aos 48 anos iniciou as tentativas para engravidar, não conseguindo obter sucesso.

Ela pensa em adoção e admitiu que gostaria de adotar legalmente um filho, mas o marido sempre descartou essa possibilidade. Tal descompasso fez com que o casal seguisse sem o filho que Salvina tanto deseja. No dia que a entrevistei ela estava com 53 anos e ainda sonhava com a possibilidade de uma gestação da forma tradicional, sem nenhum tipo de interferência médica. Quando lhe perguntei se havia desistido de engravidar, ela me respondeu: "Eu acho que ainda é possível uma gravidez... se o outro faz um gol de placa ainda posso gerar. Eu tô envelhecendo na idade na pele... mas parece que dentro de mim eu não tô envelhecendo... eu não tô velha!" (Salvina - terceira geração). ${ }^{15}$ Especificamente sobre a ausência, Salvina diz que nunca a sentiu porque sempre criou os sobrinhos, ajudando, inclusive, com recursos financeiros a sua irmã. As experiências e os cuidados que teve com os sobrinhos propiciaram a ela uma forma de maternidade. Quando lhe perguntei como descreveria uma mulher que nunca foi mãe, ela respondeu a partir da experiência de maternidade que teve com os cuidados dos sobrinhos:

Se ela [mulher que não foi mãe] não tiver a experiência que eu tenho, acho que ela será uma pessoa amarga, mal humorada, de mau humor, ranzinza, que se irrita com criança quando tá brincando, porque ela não teve o papel de mãe, não teve a experiência de ver uma criança correr, chorar, cair... (Salvinaterceira geração). ${ }^{16}$

\footnotetext{
${ }^{14} \mathrm{Em}$ sua entrevista, Salvina narra uma infância permeada de desprezo por parte do pai. Afirma que ele nunca lhe comprava brinquedos, mas que comprava para os demais irmãos. Além disso narra as brigas entre os pais por motivos de ciúmes e bebedeira paterna. Além disso, Salvina narrou a violência paterna usada para educação das crianças, afirmando que seu pai, quando batia nos irmãos, os deixava de cama. Quando ela estava com 8 anos, sua mãe fugiu de casa junto com todos os filhos. Foram moram num bairro pobre da periferia de Manaus e sua mãe, por questões financeiras, deixava os demais irmãos sobre seus cuidados.

${ }^{15}$ Entrevista concedida em 04 de maio de 2013.

${ }^{16}$ Entrevista concedida em 04 de maio de 2013.
} 
Para Salvina, em sua vida não há ausência de maternidade, tendo em vista a intensa relação que tem com os sobrinhos. Ela ajudou a criar, moraram com ela por alguns anos e se sente plenamente responsável por eles. Antes da entrevista, cheguei a me questionar se a experiência que Salvina viveu com os sobrinhos não a havia tornado, em algum grau, mãe deles. Por vezes, ela se refere a eles como "o meu menino", "a minha menina". Contudo, embora a experiência de cuidados e afetos desenvolvida por Salvina com os seus sobrinhos tenha sido forte, não representou na vida dela, efetivamente, a experiência de maternidade. Durante a entrevista, ela diz: "eu não tive filhos", "eles não são meus"; ou seja, existe a consciência de que outra mulher é a mãe deles e ela não se coloca como mãe, mas sim, como uma tia superprotetora. Perguntei se a ausência de maternidade havia influenciado em alguma coisa na sua vida, e ela me responde com certa ironia: "Acho que não... Ausência da maternidade? Não. Tenho meus sobrinhos." (Salvina- terceira geração). ${ }^{17}$

Ao longo da entrevista, ela ressalta fortemente a sua relação e dedicação com os sobrinhos, mas ainda assim insiste que gostaria de ter seus próprios filhos. Dessa forma, considero que, embora de maneira diferente, Salvina também viveu algum sentimento de ausência de maternidade. Vivenciou um desejo de filho, que ainda não pode realizar. Esse conflito entre o amor que sente pelos sobrinhos e o desejo de ter um filho nascido dela ficou evidente na fala abaixo:

Eu posso até não ter parido, mas sou tão mãe quanto as que pariram. Se alguma
coisa tá acontecendo com a Lilia e o Lucas [sobrinhos], eu sinto no meu coração.
Essa é uma relação de mãe mesmo. Eu me sinto mãe deles, tanto que a Lilia me
chama também de mãe. O Lucas já não... É que a Lilia ficou mais tempo comigo.
Mas o que eu cobiço mesmo era aquele barrigão mesmo, aquele barrigão de
mulher grávida. (Salvina - terceira geração). ${ }^{18}$

A cobiça de Salvina é uma gestação e, portanto, a concretização de um processo de maternidade e do próprio imaginário da gravidez, daí sua cobiça pelo "barrigão". As experiências maternais que ela teve e ainda tem com seus sobrinhos foram lembradas na entrevista. Porém, o fato de não ter conseguido engravidar deixou nela um desejo de filho que vai além dos cuidados e afetos que possui com os sobrinhos. Ela ainda sonha em ser mãe. Ao fim da entrevista, perguntei se ela acreditava que teria uma vida mais feliz se fosse mãe. Ela sorri e me responde: "Eu fui feliz. Talvez se eu tivesse

\footnotetext{
${ }^{17}$ Entrevista concedida em 04 de maio de 2013.

${ }^{18}$ Entrevista concedida em 04 de maio de 2013.
} 
[filho] eu seria mais feliz. Mas vamos supor... eu ainda posso engravidar. Esses dias fui no médico e ele olhou pra mim e disse: 'olhe que útero mais lindo'." 19 (Salvina - terceira geração). ${ }^{20}$

Salvina não falou em solidão ou em sentimento de ausência. Ela sentia-se pertencente a uma rede familiar que lhe ajudava e a qual ela também ajudava. Essa rede pessoal lhe propiciou experiências maternais e outras tantas lembranças que, ao fim da entrevista, embora com a ausência de uma gravidez, ela afirmou terem lhe propiciado a felicidade, mesmo sem poder realizar seu desejo de maternidade até aquele momento.

Diferente é o sentimento relatado por Victória, também pertencente à terceira geração de mulheres, nascida em 1972 na cidade de Ponta Grossa/ PR onde ainda reside. Para Victória, existe a vivência de uma ausência e o que chamo de "memória de uma ausência". Ela quer muito um filho e lembra constantemente que não o tem. $O$ sonho presente de uma maternidade ausente torna o fato de não ter filho uma lembrança constante na sua vida. Ela mencionou que nem festa de casamento tentou organizar, pois estava com pressa de ter filho. Para ela, a maternidade era algo importante no processo da vida, uma forma intensa de amor e de relacionamento com o outro. Bauman, ${ }^{21}$ ao abordar a sociabilidade, nos relata que os seres humanos se estendem na direção uns dos outros e se esforçam para transformar as presenças humanas em uniões, pois, de modo geral, anseiam pelo convívio. Nesse sentido, ainda segundo o autor, o casamento e a geração de crianças foram historicamente vistos como reforço na ideia de união. Os filhos representavam historicamente uma espécie de ponte entre a mortalidade e a imortalidade.

A vida individual é relativamente curta e, consequentemente, sua finitude induz à reflexão sobre a possibilidade de sua continuidade. Penso que a ideia de ter filhos represente para muitas pessoas, de forma material, essa ponte entre a mortalidade e a imortalidade destacada por Bauman. Victória falou de finitude, de dor e de ausência pelo fato de pensar em morrer e tudo acabar. Percurso da vida percorrido por todos nós, em diferentes ritmos e com diferentes expectativas, a morte vinha acompanhada do fim efetivo e da "memória da ausência", pois, segundo ela, se tivesse filhos, mesmo após a morte poderia, de alguma forma, continuar viva através deles. Quando lhe perguntei se ela gostaria de ter tido um filho, respondeu:

\footnotetext{
${ }^{19}$ No momento da entrevista Salvina estava com 53 anos. Ainda menstruava e alimentava o sonho de uma gestação.

${ }^{20}$ Entrevista concedida em 04 de maio de 2013.

${ }^{21}$ BAUMAN, Zygmunt. Amor líquido. Sobre a fragilidade dos laços humanos. Rio de Janeiro: Zahar, 2009.
} 
Sim. Com um filho dá impressão que não existiria mais solidão né... Porque é tão ruim ficar sozinha. Um filho é teu, teu mesmo. Esse ninguém te tira. $\mathrm{O}$ filho escreve a história sabe... a continuação de uma história. Porque comigo a história vai acabar comigo. Eu morri, acabou. Mas se eu tivesse um filho ia ser lembrada. Eu ia continuar né... assim, a mãe, a avó. Acho que é aquele negócio de ser teu mesmo, a única coisa que é teu mesmo... e que continua você. (Victória - terceira geração). ${ }^{22}$

Ao analisar sua fala e as memórias que ela me permitiu conhecer, compreendi que a articulação entre mortalidade e imortalidade mencionada por Bauman acabou por tornar o filho e a maternidade, em alguma medida, como um "objeto" de consumo emocional. A construção social feita a partir do filho como uma continuação de nossa própria existência torna a expectativa e o desejo de maternidade absolutamente funcional, ou seja, disseminou-se a ideia de que precisamos do filho para continuar a existir. Penso que um filho seja muito mais do que nossa própria continuidade, afinal, o filho é outro ser humano, com limitações e desejos próprios, muitas vezes idealizado e colocado no plano ficcional do amor incondicional.

A narrativa de Victória reforça a relação entre filho e imortalidade, de continuação dela mesma e demonstra a forma como esse tipo de estereótipo social ainda se entrelaça fortemente com as experiências, sociabilidades e subjetividades das mulheres. Pertencente à terceira geração de mulheres sem filhos, Victória idealiza a maternidade e a possibilidade de felicidade que uma criança lhe traria. Ao questioná-la sobre se acreditava que teria uma vida mais feliz caso fosse mãe, sem titubear respondeu: "Com certeza, pra compartilhar as coisas, ter com quem dividir as coisas... um futuro sabe, pensar num futuro. Talvez até mais força pra lutar contra as coisas, as incertezas, as derrotas." (Victória- terceira geração). ${ }^{23}$ Victória demonstra que se sente só. Ao longo da entrevista, por diversas vezes mencionou o fim de seu casamento, a morte do pai e da mãe e a relação com os irmãos que, embora presentes, é marcada por alguns conflitos. A solidão descrita por ela, sua queixa em não ter com quem compartilhar, não ter com quem sonhar um futuro, acabam por torná-la alguém que deseja uma vida diferente da que tem, mas que está, de algum modo, aprisionada à que possui. Victória admite que teve vontade de adotar uma criança e iniciar, assim, uma experiência de maternidade e também uma nova vida. Contudo, descartou a ideia de adoção quando descobriu que era portadora do vírus HIV. Para ela, o vírus representa uma situação real e uma

\footnotetext{
${ }^{22}$ Entrevista concedida em 01 de maio de 2013.

${ }^{23}$ Entrevista concedida em 01 de maio de 2013.
} 
potencialidade de morte que a impedem de adotar. Sente-se presa em uma realidade na qual a solidão se faz presente.

Quando Storr ${ }^{24}$ analisou a solidão, procurou, em diversos capítulos de seu livro, apontar maneiras positivas como as pessoas se relacionam com ela. Contudo, Storr debate sobre a solidão forçada, ou seja, uma solidão imposta por diferentes maneiras e que pode se apresentar de formas variadas ao longo das vidas humanas. Para Storr, a solidão forçada tem como principal exemplo as prisões, aqui falando no sentido literal, os diferentes asilos, abrigos e encarceramentos pelos quais as pessoas podem passar. Contudo, a prisão também pode ser usada num sentido de metáfora, ou seja, para representar uma situação de aprisionamento que impede a mudança. Victória sofreu com a descoberta do HIV, chegou a fazer dezoito exames de sangue para ter certeza de que era portadora da doença, e viu-se sozinha a partir de então. Seu companheiro, que lhe transmitiu a doença, saiu de casa rompendo com o casamento. Suas esperanças de filhos foram-se embora junto com o ex-marido e, devido a doenças e a incertezas que ela afirma enfrentar com relação ao seu estado de saúde, prefere não adotar nenhuma criança e permanecer só.

Sua solidão não é opcional, ao contrário, Victória desejou uma família com filhos. Projetou nos filhos imaginados o fim de seu sentimento de solidão e seu desejo de permanecer viva, de construir a "ponte" mencionada por Bauman. Contudo, sua vida seguiu por outros caminhos, e ela se viu forçada a abandonar a ideia de engravidar ou de conviver e ser responsável por alguma criança. Seu sonho de gestação começou a se distanciar da realidade quando ela parou de tomar o anticoncepcional e percebeu que não engravidava como planejado. Quando lembrou os momentos de casada em que o filho ainda era planejado, Victória misturou expressões e sentimentos, gargalhou e lacrimejou para responder a mesma pergunta. Quando lhe questionei como foi o processo de tentar engravidar, ela narrou:

Tomei vários meses ativador de ovulação. Eu estava tentando, tentando... mudando de médico. Só que como sou hipertensa, o médico queria tratar a hipertensão. Daí tomei ativador de ovulação... Daí tentei mais um pouco e o médico mandou ele [marido] fazer um exame. Ele concordou. Daí ele fez exame e deu que ele tinha poucos "aptos". Os espermatozoides dele não eram aptos para engravidar... [gargalhadas] Ficou louco, nossa! Pense num homem machista. Daí ele falou que o médico não foi com a cara dele, que ele dava conta do recado. Ele queria que eu trocasse de médico, e eu troquei. Só que eu nunca cobrei dele né... Ah, você não pode me dá filho. Isso nunca cobrei né... Mas ele me cobrava. Dizia que eu fui no médico que não era bom. Que ele não tinha problema, e

${ }^{24}$ STORR, Anthony. Solidão. A conexão com o eu. São Paulo: Paulus, 1996. 
que o problema era comigo. Nisso aí já fazia uns três anos que eu não tomava remédio pra evitar. Ele se recusou a fazer qualquer tratamento e ainda contou pros pais deles que era eu que não podia ter filho. Ele mentiu pros outros que era eu que tinha problema. Só que eu nem me preocupei... Não tinha o que fazer. Era só com inseminação artificial. Mas o próprio doutor falou pra mim repensar... porque ia ser uma gravidez de risco, porque eu já era hipertensa, já estava com 34 anos na época, pesava 118 quilos. Ele não me incentivou a fazer a inseminação. Era muito caro. Nós não ia ter condições de fazer. 0 médico disso pra rever, porque ia ser de risco, pra pensar em adoção. Daí a gente foi deixando de lado, pra gente não brigar... por causa da bebedeira dele. Porque quando ele bebia, ele falava assim "Ah, eu sou um infértil...", e quando estava são, falava que a infértil era eu. (Victória- terceira geração). ${ }^{25}$

É interessante destacar que Victória riu muito quando mencionou o fato dos espermatozoides de seu ex-marido não apresentarem condições favoráveis para a fertilização por vias naturais. Ao mesmo tempo, ela continuou com o olhar pesaroso ao explicar que, dessa forma, foi abandonando a ideia de tentar engravidar. Os obstáculos eram muitos: a idade que não era considerada pelo médico como favorável, o seu peso e a sua situação de hipertensa. Além disso, o maior obstáculo era a recusa do marido em fazer algum tratamento ou aceitar a ideia de inseminação artificial. Por diversas vezes ao longo da entrevista, ela ressaltou que procurou não culpar o marido nem pela sua baixa fertilidade e nem pela recusa em tentar algum tratamento. Ao invés de culpar o companheiro, Victória afirmou que sentia pena dele. A bebida é mencionada em vários momentos da entrevista. Segundo Victória, ocorria uma transformação no relacionamento e na afetividade de seu companheiro quando bebia e, para ela, foi a bebida e as constantes traições do marido que acabaram pondo fim ao casamento, e não a ausência de filho ou a recusa do marido em adotar alguma criança.

Denise Jardim ${ }^{26}$ ao fazer um estudo etnográfico sobre performance, reprodução e produção dos corpos masculinos, observou que tais corpos também possuem como um de seus focos a construção de um pertencimento, que a autora classificou como "comunidade de destino". ${ }^{27}$ Ao entrevistar homens

\footnotetext{
${ }^{25}$ Entrevista concedida em 01 de maio de 2013.

${ }^{26}$ JARDIN, Denise. "Performance, reprodução e produção dos corpos masculinos”. In: Corpos e significados: Ensaios de antropologia social. Porto Alegre: UFRGS, 2001.

${ }^{27}$ A autora articula os conceitos de masculinidades e destino a partir das reflexões de Bourdieu (1990). Para Jardim (2001) as identidades construídas socialmente podem se transformar na noção de destino. Não apenas um destino biológico que foi elaborado socialmente sobre o signo da diferença mas também as diferenças físicas e de condições físicas são percebidas nas "comunidades masculinas" como possíveis de produzir destinos. Por "comunidades masculinas" entende-se a partir do estudo de Jardim, os bares e botecos, onde os homens partilhavam experiências e demostravam ou não o controle sobre seus corpos,
} 
frequentadores de bares e botecos em Porto Alegre/RS, Jardim percebeu que um dos pontos ressaltados e valorizados pelos homens como um bom exercício de masculinidade, era o controle sobre a bebida. Beber e ser carregado, beber e cair ou beber e não pagar eram sempre apontados como elementos de exclusão do grande grupo de sociabilidades dos bares na capital gaúcha. Além disso, Jardim observou que os sentimentos e afetos permitidos a serem expressados nos bares pelos homens eram aqueles relacionados aos filhos. Fazer filhos e conseguir provê-los foram ações mencionadas pelos homens entrevistados por Jardim como um elemento central na construção de um "destino" masculino. Dessa forma, os problemas de família relatados a ela nos botecos eram sempre problemas com filhos. A paternidade foi mencionada como uma condição de ascensão na condição masculina. Assim, a condição de pai era o que determinava por completo a condição de homem. Tal relação (masculinidade e paternidade) foi encontrada em todas as entrevistas realizadas pela autora ao longo do ano de 1991, em diferentes bares frequentados pelas camadas populares de Porto Alegre. Assim, ao relacionar as reflexões de Jardim com as lembranças de Victória sobre seu ex-marido, acredito que a "compaixão" que ela demonstrou em diferentes momentos, ao tratar das lembranças de seu casamento, se referem, em certa medida, a essa "incompletude" que acompanhava a masculinidade dele. Victória ressaltou que quando ele aparecia em casa bêbado ficava pelos cantos afirmando que era "um infértil”. Porém, nos momentos em que não estava influenciado pelo álcool, ele mencionava que era ela que apresentava problemas para engravidar, ou seja, nos momentos de lucidez, quando era necessário ou solicitado dar alguma explicação para amigos e familiares, ele espertamente optava por culpá-la pela ausência de filhos.

O descontrole do ex-marido com relação à bebida causava em Victória sentimentos contraditórios. Em certa medida, ela afirmou sentir pena de sua condição de alcoólatra, mas, por outro lado, se mostrou profundamente irritada quando lembrava as cenas de vexame que o ex-marido lhe obrigava a passar devido a sua dependência. Ela contou com detalhes as festas e eventos familiares em que era obrigada a se retirar para evitar a bebedeira, ou então as brigas que ele arrumava devido à bebida. A suposta piedade de Victória permitiu que ele mentisse para os amigos e familiares com relação a sua fertilidade e, segundo ela, "nem ligou" para este fato, pois via nele alguém frágil demais, ou seja, alguém que rompia com a "comunidade de destino" dos

especialmente se tratando sobre o controle da sobriedade depois de alguma bebida. 
homens estudados por Denise Jardim. O ex-marido de Victória não atingiu a paternidade, não tinha controle sobre seus vícios (nem de bebidas e nem de mulheres) e não era o provedor da casa. Assim, ela o citava na entrevista com o sentimento de pena, mesmo sendo ele o transmissor do vírus HIV. Compaixão, pena e piedade foram os sentimentos citados por ela. Acrescento a estes, o sentimento de alguma indiferença, pois, na entrevista, Victória cita um namorado anterior ao casamento. Falou longamente sobre esse primeiro relacionamento, o noivado e o término da relação, mencionando o período que estiveram juntos e o seu nome. Já, quando narrou seu casamento, sempre se referiu ao seu antigo companheiro como "ele", ou então "meu ex-marido". Victória não citou sequer seu nome.

Contudo, apesar de relatar que "ele" foi o culpado pela transmissão de sua doença e também por dificultar sua realização de maternidade, compreende seu ex-marido como um coitado. Da mesma forma, Jardim ${ }^{28}$ identificou que homens sem filhos foram percebidos e descritos como inferiores, pois não possuíam a "marca de distinção" para a produção de uma autoimagem de virilidade, ou seja, não possuíam condições físicas ou econômicas de ter filhos. A paternidade ainda é um campo de estudo em busca de pesquisadores. Pouco sabemos sobre as experiências de paternidade ou de infertilidade masculina analisada pelo viés das subjetividades e das interferências nas relações afetivas. Contudo, por meio da entrevista de Victória, percebi que padrões e estereótipos com relação à virilidade também se relacionam com a capacidade de produzir crianças. Ele, contudo, não foi descrito como um homem solitário. Viveu com Victória seu segundo casamento e foi descrito como rodeado de amigos. Ela, todavia, se descreveu como uma mulher sozinha, apesar da presença dos irmãos e amigos. Vive em uma casa com seu irmão. Mas, por diversas vezes reclamou que lhe falta companhia, lhe falta alguém com quem dividir os sonhos e a vida. Porém, retomando a noção de prisão forçada desenvolvida por Storr, ${ }^{29}$ Victória compreende que o fato de ser portadora do vírus HIV lhe impede de buscar um novo relacionamento afetivo. Sente-se aprisionada em uma solidão que não consegue, ou que não quer transpor.

Assim, ela evitou algumas aproximações amorosas e descartou por completo a possibilidade de adotar uma criança. Victória construiu sua narrativa demonstrando que o vírus, os cuidados com a saúde e os exames rotineiros

\footnotetext{
${ }^{28}$ JARDIM, op cit.

${ }^{29}$ STORR, op cit.
} 
tomam conta de boa parte de sua vida. Sendo assim, mesmo desejando e sonhando com a maternidade, ela preferiu abandonar a ideia de ter um filho. Sua abdicação foi narrada de forma altruísta, pois mencionou como centro de preocupação a vida da suposta criança adotada. Para Victória, não seria justo adotar uma criança que já passou por uma situação de abandono e conviver com ela por algum tempo. Porém, usando como argumento o contágio do HIV, ela evidenciou que pode morrer a qualquer momento, que pode não ter tempo para criar essa criança adotada e que novamente a criança seria abandonada. Alegando isso e chorando muito, ela disse com confiança que preferia não ser mãe, que preferia não adotar ninguém.

A solidão que Victória alega sentir e conviver lhe traz melancolia e algumas idealizações com relação à presença de um companheiro ou mesmo de um filho. De certa forma, considerei que Victória, no momento da entrevista, quis mostrar que sofria de solidão. Contudo, nem todas as mulheres que não possuem filhos e que moram sozinhas pareceram-me incomodadas com a solidão. Eliane Gonçalves ${ }^{30}$ desenvolveu pesquisa sobre mulheres que moram sozinhas na contemporaneidade, e argumentou que a percepção de solidão não deve ser obrigatoriamente vinculada às mulheres que vivem sós. Mesmo no caso de mulheres mais idosas, a solidão não apareceu em todas as entrevistas de Gonçalves e, tampouco, em todas as entrevistas realizadas por mim. Viver só não significa viver em solidão. Essa afirmativa vale para as três gerações de mulheres estudadas nesse trabalho.

Penso que todos nós, em diferentes momentos da vida, sentimos solidão, sentimos a ausência de alguém ou de algo. Portanto, as mulheres e as histórias que estão no próximo tópico não são imunes aos sentimentos aqui tratados. Considerei apenas que, no momento da entrevista, elas desejaram construir para mim uma imagem que as distanciasse do estereótipo de solitárias, sofredoras e desejosas de filhos a qualquer preço.

\section{Nem só, nem mal acompanhada}

Tendo conquistado o direito de ficar só [...], tendo se libertado da generalização de que os humanos estão condenados a sofrer de solidão, pode-se assegurar: vire-se a solidão de cabeça para baixo e ela se transforma em aventura (Theodore Zeldin).

\footnotetext{
${ }^{30}$ GONÇALVES, Eliane." Nem só, nem mal acompanhada: reinterpretando a "solidão" das "solteiras" na contemporaneidade". Horizontes Antropológicos, Porto Alegre, ano 15, n 32, p 189-216, jul-dez, 2009.
} 
As mulheres pertencentes à primeira geração aqui estudada convivem com o fato de morarem sozinhas de maneira prática e objetiva. Não houve espaço para choros, grandes lamentações ou longas falas sobre ausência e solidão.

Esther, nascida e 1929 na cidade de Ireneópolis/SC e residente em Ponta Grossa/PR, Maria Clara, nascida em 1939 em Reserva/PR, onde ainda reside, e Ernestina, nascidas em 1934, em Cândido de Abreu/PR e residente em Ponta Grossa/ PR, pouco se queixaram de solidão ou mesmo de ausência de filhos. Todas solteiras, não tiveram muitas opções para construir afetos filiais, tendo em vista a ausência de matrimônio em épocas que um filho fora de um casamento poderia significar a "desgraça moral" de uma mulher. Embora em alguns momentos das entrevistas, a ausência de filhos fosse relatada com certo pesar, não se tratava de falta de ter embalado alguém, ou falta das noites em claro cuidando de bebês. Elas, idosas, solteiras e sem filhos, falavam da ausência a partir de sua realidade atual, ou seja, do cotidiano caseiro aos $70 \mathrm{ou}$ 80 anos sem ter um filho para quem gritar caso necessitem. É um sentimento de ausência percebido muito mais em termos de "utilidade em ter filho" do que em "afetividades com filhos".

Não encontrei nas entrevistas com a primeira geração de mulheres nenhum sonho terno e suave de maternidade idealizada. Elas não foram mães e tratam desse fato com certa indiferença ou desimportância. Enquanto as mulheres da terceira geração podem ser divididas no grupo das que gostariam muito de ter filhos e não conseguiram e no grupo das que optaram por não ter filhos, as mulheres que fazem parte da primeira geração apresentam maior homogeneidade na narrativa sobre a ausência de maternidade. A vida foi caminhando pra isso e a solteirice impedia qualquer sonho planejado de maternidade naquela época.

Esther, que me concedeu entrevista em 2013, com 83 anos e morando absolutamente sozinha, não lamentou a ausência de filhos. Tampouco supôs que a maternidade poderia modificar algo na vida ou na personalidade feminina. ${ }^{31}$ Para ela:

\footnotetext{
${ }^{31}$ É interessante destacar aqui que todas as entrevistas pertencentes à terceira geração (mulheres nascidas nas décadas de 1960 e 1970), ao serem questionadas sobre se a maternidade poderia mudar algo na personalidade da mulher, afirmaram que "sim". As mulheres que desejavam ter filhos, e não conseguiam, descreveram a maternidade como capaz de tornar as mulheres mais sensíveis, felizes e doces. Já as mulheres que não desejavam ter filhos ou que nunca tentaram engravidar, percebiam a maternidade como elemento capaz de mudar o cotidiano da mulher, além da personalidade. As mães supostamente teriam mais afazeres e menos tempo. Eram mulheres desdobráveis. A terceira geração de mulheres não-mães descreveu a maternidade como ternura, sensibilidade, agitação, dedicação, falta de privacidade. Todas as descrições vinham acompanhadas da constatação de que a maternidade muda a mulher (verdade para a
} 
A maternidade não muda a personalidade da pessoa, não muda o jeito de ser. A personalidade e o caráter nascem com a pessoa. Ser ou não ser mãe não muda quem você é. Eu na verdade nunca pensei em ser mãe, esse pensamento nunca me ocorreu. Acho que gostaria de ter tido um filho, porque todos gostam, mas nunca me acorreu como uma possibilidade concreta. Sempre achei uma responsabilidade muito grande colocar uma pessoa no mundo, porque e se aquela pessoa não é feliz? E se eu não for feliz depois de ser mãe? A responsabilidade muito grande porque ter e deixar que viva ao Deus dará também não dá né. (Esther- primeira geração). ${ }^{32}$

A narrativa de Esther foi emblemática. Ela apontou sua carreira, suas viagens pelo Brasil e pelo exterior. Falou sobre as greves que enfrentou como docente da educação básica do Paraná, e nos instantes em que as questões eram direcionadas à maternidade e à ausência de filhos, ela se questionava se realmente algum dia quis ter filho. Nascida em 1929, no interior de Santa Catarina, em uma família de muitos filhos, Esther não estava plenamente convencida de que a falta de filho poderia trazer solidão ou algum sentimento de ausência.

Aminatta Forna ${ }^{33}$ escreveu que existem vários roteiros para a maternidade, destacando o incômodo que algumas mulheres sentem com a chegada de um bebê, ou mesmo as diferentes formas de se construir o amor maternal. Aqui se percebe que também existem diferentes caminhos e sentimentos para a não-maternidade. A ausência de filhos não é dor. Aliás, a dor e as lágrimas apareceram muito pouco nas entrevistas.

Também a primeira geração apresentou outra característica peculiar. Nenhuma delas afirmou que passou por algum tipo de discriminação por não ter filho. Nenhuma disse que foi excluída parcialmente de conversas pelo fato de não ser mãe, e nenhuma pensou em adoção. Acredito que essas respostas reforçam a articulação entre maternidade e casamento que existia para essas mulheres nascidas nas primeiras décadas do século XX. Esther, Maria Clara e Ernestina tiveram e cuidaram de irmãos. Depois, em alguma medida, se responsabilizaram por sobrinhos e sobrinhas e, portanto, possuíam conhecimentos sobre partos, cuidados com filhos e mesmo com a maternidade.

Dessa forma, nunca sentiram, ou não relatam nenhum tipo de mal-estar quando as conversas nas rodas de amigos ou familiares caminhava para as

terceira geração). Esse tipo de entendimento sobre a maternidade não foi constatado em todas as mulheres da primeira ou da segunda geração.

${ }^{32}$ Entrevista concedida em 26 de abril de 2013.

${ }^{33}$ FORNA, Aminatta. Mãe de todos os mitos: como a sociedade modela e reprime as mães. Rio de Janeiro: Ediouro, 1999. 
lidas com as crianças, ou mesmo histórias de partos. ${ }^{34}$ Sendo as três solteiras, o que se esperava delas era justamente o que forneceram: que cuidassem dos irmãos, irmãs e sobrinhos.

Goran Therborn ${ }^{35}$ argumenta que, no início do século XX, o casamento era, em essência, um importante arranjo de procriação. Dessa forma, era pelo casamento que se legitimavam os "frutos da sexualidade". Com isso, somente com a efetivação de um casamento se poderia pensar numa descendência legítima e gloriosa. Solteiras, provavelmente se possuíssem filhos seriam discriminadas. ${ }^{36}$ Nesse sentido, tais mulheres também foram unânimes em relação à possibilidade de adoção. Nenhuma sequer cogitou a possibilidade de se responsabilizar legalmente por uma criança, ou mesmo de "pegar pra criar" criança de algum conhecido ou amigo.

Elas ajudaram suas mães e, posteriormente, ajudaram suas irmãs a criar sobrinhos, mas não pensavam em ser chamadas de mães. Tal fato é descrito nas entrevistas de maneira muito breve e objetiva. Quando questionei as mulheres da primeira geração sobre adoção, as respostas foram curtas: "não, nunca pensei".

A ideia de maternidade para as mulheres da primeira geração se relaciona muito mais com trabalho do que com idealizações de amor ou de afetividade. Existiu, pelo menos nas entrevistas, uma ponderação maior sobre o que significaria uma criança na vida, principalmente nas falas da primeira e da segunda gerações. Dessa forma, as mulheres mais velhas se "culpam" menos pela ausência de filhos e, portanto, se justificam menos também. Não existiram longas narrativas sobre os caminhos percorridos até a velhice sem filhos, as falas mais objetivas e práticas demonstraram que elas não sentiram ausência ou dor pela ausência. Deram novos significados à vida a partir de sua condição de solteiras ou, então, de seus trabalhos e cuidados com familiares.

\footnotetext{
${ }^{34}$ As mulheres da terceira geração relatavam desconforto ou mesmo exclusão quando a conversa entre amigas caminhava para as atividades com filhos ou a maternidade em geral.

${ }^{35}$ THERBORN, Goran. Sexo e poder: a familia no mundo 1900-2000. São Paulo: Contexto, 2006.

${ }^{36} \mathrm{Em}$ meu estudo de mestrado também orientado pela professora Dr. ana Paula Vosne Martins, e defendido em 2005, analisei mulheres envolvidas em casos de aborto e infanticídio. Tais mulheres eram sozinhas, ou seja, solteiras ou viúvas. Os processos e inquéritos são datados do final do século XIX até a década de 1970, e em todos os depoimentos das mulheres foi observado que a "honra" de tais mulheres estava em risco caso assumissem a gravidez estando solteiras. Como engravidaram, precisavam dar fim na gestação ou na criança para conseguir manter a moral, a reputação e mesmo a sobrevivência, tendo em vista que não tinham condições de manter uma criança sozinhas. Dessa forma, percebi que uma criança na vida de uma mulher solteira na primeira metade do século XX era motivo de desespero e não de "amor materno". As entrevistadas da primeira geração (Esther, Maria Clara e Ernestina) até se mostraram surpresas, ou riam quando lhes perguntei se em algum momento sentiram-se discriminadas por não terem filhos. Sendo solteira, a ausência de filhos não causaria discriminação, mas a presença de filhos sim.
} 
Tais narrativas possibilitaram a percepção de como as mulheres incorporaram de maneiras e intensidades diferentes os discursos sociais que articulavam a figura feminina com a maternidade.

Nas entrevistas com a segunda geração de mulheres (nascidas nos anos de 1940 e 1950), encontrei um padrão de discursos muito parecido com o da primeira geração. Catarina, nascida em 1946 no município de Reserva/Pr onde reside até a atualidade, afirmou que em seu cotidiano não existe espaço para sentir solidão. Ela narrou seus dias da seguinte forma:

Eu moro com minha irmã. E a vida é assim, levantamos às 6 horas da manhã. Cedinho já estamos de pé pra tomar café. Daí vamos tratar a criação... eu vou na horta, as vezes pro mercado. Vamos na igreja, todo dia é a mesma coisa. A gente assiste TV um pouco, mas muito pouco... às vezes de manhã assistimos a Rede Aparecida, a missa, mas é mais a noite que assistimos. Não tem solidão, tem que lidar com criação e fazer coisas o dia inteiro. (Catarina - terceira geracão). ${ }^{37}$

Como Catarina e Maria Clara são irmãs, vivem num pequeno sítio, muito próximo à cidade de Reserva, conseguem permanecer na propriedade e, ao mesmo tempo, vivenciar sociabilidades da cidade como frequentar a igreja matriz ou mesmo festas religiosas e familiares. Especificamente com relação à ideia de ter filhos, Catarina manteve a visão já trabalhada aqui de que mulheres não deveriam ter filhos estando solteiras. Além de descartar completamente a adoção e afirmar que jamais tal ideia lhe ocorreu, Catarina demonstrou acreditar que ter um filho sem estar acompanhada de um marido seria algo inadequado e, ao invés de lhe trazer companhia ou felicidade, poderia ser visto como um problema. Para ela, filho sem marido não valia a pena:

Não teria filho não. Nunca nem pensei em ter um filho sozinha. Acho que não sendo casada não dá pra ter filho...Tem os sobrinhos que me respeitam como mãe, eu cuidava dos 5 filhos do irmão, já tá bom né! Hoje eles cuidam de nós como se nóis [sic] fosse mãe deles. Do segundo banho em diante era eu quem dava. (Catarina - segunda geração)..$^{38}$

A narrativa de Catarina vai ao encontro das reflexões de Maria Izilda Matos $^{39}$ sobre o questionamento da universalização de sentimentos. Quando perguntei a Catarina se ela gostaria, se fosse possível, de vivenciar a maternidade, ela me respondeu que "sim". Disse que achava bonito ser uma mulher mãe e queria ter filhos, se possível. Todavia, devido a sua condição de solteira,

\footnotetext{
${ }^{37}$ Entrevista concedida em 02 de junho de 2013.

${ }^{38}$ Entrevista concedida em 02 de junho de 2013.

${ }^{39}$ MATOS, Maria. I. Âncora de emoções - corpo, subjetividades e sensibilidades. Florianópolis: UDUSC, 2005.
} 
mesmo tendo possibilidades financeiras, nunca considerou a possibilidade de engravidar ou adotar uma criança. Para Matos, é preciso discutir como os comportamentos, valores e sentimentos são aceitos em um determinado período/sociedade e como podem sofrer alterações, posteriormente, sendo até rejeitados por completo. Nesse sentido é que a autora aponta para a impossibilidade de universalização de desejos e de sentimentos, sendo que tais subjetividades são modificadas por meio das relações sociais e, portanto, históricas.

Enquanto mulheres da primeira e da segunda gerações, não cogitavam a possibilidade de ter filhos estando solteiras, devido, seguramente, a padrões morais estabelecidos socialmente, fortemente reforçados na primeira metade do século XX, as mulheres da terceira geração não relacionam a necessidade de casamento para a realização de gravidez ou de adoção.

Mesmo tratando da história de Victória, que afirmou desejar um filho acompanhado dos "benefícios" que ele traria, ou seja, acompanhado de um marido para dividir atividades, pode-se perceber modificações significativas com relação às falas da primeira e da segunda gerações de mulheres. Victória considerou a possibilidade de adoção e, mesmo após a separação matrimonial, afirmou que gostaria de adotar, porém, ponderou e recuou em sua vontade quando descobriu ser portadora do HIV. Não foi o fim do casamento ou a volta à solteirice que impediu Victória de engravidar ou de adotar, foi sim o vírus que, segundo ela, lhe impede de tomar tal decisão.

As nascidas entre os anos de 1960 e 1970 não tiveram filhos por motivos variados, desde a opção pela não-maternidade, a dedicação à carreira ou mesmo questões ligadas à infertilidade. Porém, solteiras, casadas ou separadas em momento algum afirmaram que não tiveram filhos por estarem sem marido ou pelo medo de ficarem sem marido. Os caminhos, escolhas e possibilidades para as mulheres da terceira geração são mais amplos. Assim, a decisão de não ter filhos pode ser, simplesmente, apenas mais uma das muitas escolhas da vida.

Jane, nascida em 1974 e moradora de União da Vitória/PR, escolheu não ter filhos. Na história de Jane, não existe nenhum problema de infertilidade, nenhum traço de vida solitário ou nenhum remorso ou tristeza por não ter filhos. Ela teve muitos namorados em sua juventude, casou em $2004 \mathrm{e}$ permanece casada até hoje. Ela afirmou que se sente feliz e realizada no casamento e que na verdade nunca pensou em ter filhos ou que um filho deveria obrigatoriamente fazer parte de seu casamento e de seu mundo.

Nunca chegou a tentar engravidar, e na única vez que suspeitou estar grávida não se sentiu à vontade com a ideia. Segundo ela, felizmente não se 
tratava de uma gravidez, e sim de uma intoxicação alimentar. Mas, a simples possibilidade de engravidar lhe fez redobrar os cuidados, para que durante seu casamento isso não ocorresse. Para Jane, um filho não teria espaço em sua vida, pois:

Logo nos primeiros meses do casamento teve um dia que passei mal, com enjoo, mas foi por conta de uma intoxicação alimentar. Levamos um pequeno susto pensando que pudesse ser gravidez. Conversamos e dissemos que se fosse tudo bem, teríamos uma criança, mas que foi bom não ser. Estávamos terminando a faculdade, os dois. Não era hora. Pra gente, se tivéssemos um filho gostaríamos de educar 'do nosso jeito', não queríamos ter uma criança para deixar na creche o dia inteiro, com babá ou avó a noite e ver de fato só no fim de semana. Não queríamos que a criança passasse por isso também. Fomos fazendo escolhas. Terminamos a faculdade, comecei a especialização, começamos a pensar em comprar casa, comecei a trabalhar na minha área de formação e me encaminhar para o mestrado. Gostamos de viajar sempre que possível nessa nossa vida corrida. Uma criança não fazia parte desse nosso mundo, desses nossos planos. Há pouco tempo, no ano passado, fui a um médico para uns exames de rotina e descobri que tenho propensão a hipotireoidismo. O médico alertou que isso se intensifica com uma gravidez e que pode gerar má formação no feto. Quando contei isso ao meu marido ele disse: 'viu só, tomamos uma decisão acertada na vida, mesmo sem saber. Não seremos responsáveis por colocar no mundo uma criança que pode sofrer'. Nunca descartamos a possibilidade de um dia adotar uma criança. Mas não temos essa intenção agora e nem pensamos nisso. (Jane- terceira geração). ${ }^{40}$

Jane não mencionou solidão ou sentimento de ausência. Para ela, a vida, a profissão e o casamento lhe ocupam os dias. É necessário destacar que Jane está casada e, portanto, diferente da condição de Victória, Jane desfruta de companhia afetiva. Dessa forma, não existiu na narrativa de Jane nada que remetesse à ideia de sofrimento pela ausência de filhos. Quando perguntei se nunca pensou sobre a maternidade como uma possibilidade concreta, ela respondeu:

Não. Se eu tivesse tido [filho], seria feliz por ter tido. Não tive e sou feliz sem ter tido. Me irrita profundamente quando dizem que mulheres que não são mães não conhecem o amor verdadeiro. Me poupem, amo verdadeiramente as pessoas. Não sei o que é amor de mãe, mas sei o que é amor de esposa, de filha, de irmã, de amiga, de madrinha, de tia, de professora e esses amores são verdadeiros. Não sinto falta de ter tido um filho. Não me sinto incompleta por não ter sido mãe, não sinto que deveria ter tido essa 'experiência'. Às vezes vejo até como muito egoísta, mulheres desesperadas por terem um filho, por engravidarem quando por algum motivo não podem. Tudo bem, estou

${ }^{40}$ Entrevista concedida em 28 de abril de 2014. 
julgando e isso não é bom, mas olho pra isso e penso que é egoísmo porque estão pensando em si, numa vontade louca de ver a barriga crescer, de sentir uma criança se mexer dentro de si, o que para mim sempre pareceu ser uma experiência muito esquisita, querer ter uma criança parecida com a gente ou com o marido. Não pensam que tal criança pode sofrer nesse mundo doente e que tem crianças abandonadas por aí que precisam de mães. Nunca entendi esse desejo de 'ser mãe' tendo que engravidar. Até entendo a vontade de ser mãe, de acompanhar o crescimento de uma criança, de cuidar, de ver aprender as coisas... crianças são fofas e conheço algumas que nos fazem acreditar que a humanidade tem futuro. Mas não entendo porque esta criança não pode ser um filho adotado ou filha adotada. Quando me perguntam quem vai cuidar de mim quando eu envelhecer, eu penso novamente no egoísmo do ser humano, não só querem ter um bebê para satisfazer sua vontade de engravidar como querem traçar seu destino: terá que cuidar dos pais quando crescer. Quando eu envelhecer, se eu não conseguir mais cuidar de mim mesma antes de morrer vou para um asilo que vou pagar com minha aposentadoria. Não vou fazer ninguém cuidar de mim por conta de nenhum tipo de obrigação moral. (Janeterceira geração). ${ }^{41}$

Ao ouvir a narrativa de Jane, tão determinada com relação à ausência de filhos e, principalmente, ao analisar a construção discursiva que ela criou para legitimar sua não-maternidade, relacionei suas falas e sentimentos com as reflexões desenvolvidas por Zeldin, ${ }^{42}$ quando analisou a imunidade que algumas pessoas adquirem à ideia de solidão. Zeldin abordou a história de Colette que, ao contrário de Jane, tem filhos, trabalha e prefere morar no centro da cidade para que todos a visitem. Segundo o autor, Colette afirma que nunca sofreu de solidão, justamente porque casou e tem filhos, além de uma carreira bem estruturada. Colette jamais aceitaria a possibilidade de ficar só. Para ela, estar só e a solidão são a mesma coisa e, portanto, gosta de viver rodeada de pessoas.

De acordo com as considerações de Zeldin, o medo da solidão funciona como uma corrente que impede uma vida mais plena. Fomos acostumados a reconhecer como legítima e única a história que desde sempre as pessoas vivem em famílias e tribos e, portanto, a possibilidade de um dia estar fisicamente só ainda causa certa repulsa em boa parte das pessoas. Pouco existiu, até meados do século XX, a possibilidade de nos pensarmos como indivíduos independentes, e isso acompanhava a ideia de sempre pensar em filhos, pois significaria sempre ter alguém que dependa ou que nos ajude. Para Zeldin, só

\footnotetext{
${ }^{41}$ Entrevista concedida em 28 de abril de 2014.

${ }^{42}$ ZELDIN, Theodore. Uma história íntima da humanidade. Rio de Janeiro: Record, 1994.
} 
conseguiremos nos relacionar com os demais de forma a manter o respeito mútuo se eliminarmos o medo de estarmos sós.

Jane conseguiu, ou fez parecer ter conseguido, abolir o medo de estar só. Quando afirmou que não pensava em filhos para cuidar dela na velhice, que aceitaria ficar num asilo pago com sua aposentadoria e que as pessoas, via de regra, têm filhos por motivos egoístas, ela demonstrou que rompeu com a ideia de que mulheres sem filhos são solitárias e tristes. Os outros amores que sentiu e sente ao longo da vida lhe possibilitaram felicidades e experiências ricas. Dessa forma, ela acredita que o amor de filho ou de mãe não são coisas imprescindíveis em sua vida. Além disso, ela não se sente só.

Carolina, nascida em 1966, também afirmou não sentir solidão. Ela teve vários namorados. Casou, separou-se e no momento da entrevista estava solteira, vivendo absolutamente sozinha em sua casa. A família foi uma constante em sua entrevista. Ela relatou longamente sobre sua irmã, seus sobrinhos e a própria mãe. Contudo, manteve a escolha de morar sozinha após a separação conjugal, como forma de preservar sua intimidade. Quando questionei como era seu atual cotidiano, me respondeu: "Eu moro sozinha e gosto. Tenho uma rotina particular, só minha. Não tem solidão...eu gosto de estar só. Eu convivo bem com a solidão, melhor, comigo mesma. Fiquei chata que Deus me livre. Homem 'meia boca' não quero." (Carolina- terceira geração). ${ }^{43}$

Sem medo de sentir solitária, ela preferiu morar sozinha e resolver seus próprios problemas. Desejou uma gravidez, sofreu um aborto e, por fim, desistiu de engravidar e de manter a relação afetiva conjugal com seu par. As decisões tomadas por Carolina não foram resultado de um processo rápido. Decidir romper com o casamento demorou muitos anos para se realizar, pois havia dúvidas e questionamentos sobre como seria a vida depois da separação, ou seja, como seria viver só, pelo menos por algum tempo.

Percorrendo o tema da solidão através das memórias femininas nos Estados Unidos, Mara Sapon-Shevin ${ }^{44}$ argumenta que existem variadas mensagens e discursos que reforçam a ideia de que as mulheres devem temer a solidão. Isso vai desde a chamada solidão física, como estar sozinha na casa à noite, andar sozinha pelas ruas, viajar sozinha, ou mesmo a solidão afetiva, que significa estar sem um par. Romper com o medo da solidão que foi sendo construído e faz parte, em maior ou menor grau, da vida de todos nós, é um

\footnotetext{
${ }^{43}$ Entrevista concedida em 08 de maio de 2013.

${ }^{44}$ SAPON-SHEVIN, M. "Reclaiming the safety of solitude: being with, not hiding from". In: The center of the web: women and solitude. New York: State University of New York Press, 1993.
} 
desafio. A maioria das mulheres apresentadas neste artigo conseguiu, em maior ou menor grau, romper com isso.

\section{Considerações finais}

Não tive filhos, não transmiti a nenhuma criatura o legado da nossa miséria. (Machado de Assis)

No imaginário coletivo, foi se consolidando a ideia de que filhos poderiam livrar mulheres da solidão. Porém, muitas mulheres já não associam filho com ausência de solidão. Aliás, acredito que nenhuma das gerações de mulheres aqui estudadas faz de forma majoritária a ligação entre maternidade e companhia.

Algumas desejaram e desejam filhos, outras optaram por vidas sem filhos, outras ainda foram conduzidas para uma vida sem filhos por ausência de casamento ou de um par afetivo. Porém, o que fica evidente em suas narrativas são as múltiplas formas de ser.

O modelo de maternidade hegemônico acabou por afastar muitas mulheres do desejo de ter filho. Nenhuma mulher que entrevistei afirmou não gostar de criança. Contudo, muitas delas afirmaram que jamais seriam capazes de "cumprir" as obrigações que a maternidade exige. A recusa não está na criança em si, mas se trata de uma recusa ao modelo de maternidade imposto.

Com isso, não afirmo que todas desejaram ser mães. Mas afirmo que o modelo de mãe onipresente cria padrões excludentes, tanto para as mães como para aquelas que não são mães.

Todas elas contaram histórias singulares. Todas elas escaparam de rígidos modelos e categorias previamente definidas. Querer ter filho e não conseguir pode doer de maneira diferente. Pode não doer. O mesmo pode ser dito sobre ficar solteira ou morar sozinha. Escolher outras formas de afeto, de vida, de sonhos e ter que justificar a ausência de filhos pode incomodar de maneiras diferentes, ou nem incomodar. A articulação entre maternidade e destino foi rompida, ao menos parcialmente, para a maioria das mulheres entrevistadas. É certo que para algumas a maternidade ainda é o sonho idealizado, mas destino não é mais.

Artigo recebido para publicação em 28/08/2016

Artigo aprovado para publicação em 09/11/2016 